\title{
Normal HC11 and ras-transformed mouse mammary cells are resistant to the antiproliferative effects of retinoic acid
}

I. Snitcovsky', M.L.H. Katayama ${ }^{2}$, M.A.A.K. Folgueira ${ }^{2}$ and M.M. Brentani ${ }^{2}$
${ }^{1}$ Laboratório de Oncologia Experimental, LIM-24, Hospital das Clínicas, and ${ }^{2}$ Disciplina de Oncologia, Departamento de Radiologia, Faculdade de Medicina, Universidade de São Paulo, São Paulo, SP, Brasil

\section{Correspondence}

M.M. Brentani

Disciplina de Oncologia

Departamento de Radiologia

FMUSP

05508-900 São Paulo, SP

Brasil

Presented at the I Symposium on Advances in Medical Research, Institute of Medical Investigation Laboratories, HC-FMUSP, São Paulo, SP, Brazil, March 21-22, 2003.

Publication supported by FAPESP

Received June 16, 2003 Accepted July 31, 2003

\begin{abstract}
The objective of the present study was to determine the effects of retinoic acid on the growth of the mouse mammary cells $\mathrm{HC} 11$ and HC11 ras, which are a model for in vitro breast cancer progression. The expression of the two classes (RARs and RXRs) of retinoic acid receptor mRNAs was determined by Northern blot analysis. Receptor functional integrity was determined by testing whether RAR $B$ mRNA could be induced by retinoic acid. The effects of a 72-h exposure to 50 $\mu \mathrm{M} 13$-cis retinoic acid on $\mathrm{HC} 11$ and HC11 ras cell proliferation and HC11 cell differentiation were investigated by flow cytometric cell cycle analysis, and by determination of ß-casein mRNA expression, respectively. The possibility that retinoic acid would induce the expression of the vitamin $\mathrm{D}$ receptor and synergize with vitamin $\mathrm{D}$, a known inhibitor of $\mathrm{HC} 11$ cell growth, was also investigated. HC11 cells expressed higher mRNA levels of both RAR $\alpha$ and RAR $\gamma$ when compared to HC11ras cells. In contrast, RAR $\beta$, as well as RXR $\alpha, \beta$ and $\gamma$ expression was low in both $\mathrm{HC} 11$ and HC11ras cells. In addition, RAR $\beta$ mRNA was induced by retinoic acid treatment in both cells. In spite of these observations, no effects were seen on cell proliferation or differentiation upon exposure to retinoic acid. Neither vitamin $\mathrm{D}$ receptor induction nor synergy with vitamin $\mathrm{D}$ on growth inhibition was observed. We conclude that the RAR expression profile could be related to the transformed state in HC11ras cells and that the retinoic acid resistance observed merits further investigation.
\end{abstract}

\section{Introduction}

Murine carcinogenesis in several organs, including the breast, is inhibited by retinoids (1). Data showing the growth inhibiting effect of retinoids on murine breast tumors induced by $\mathrm{N}$-nitromethylurea (2) have in-
Key words

- Retinoic acid receptors

- Mouse mammary cells

- HC11ras cells

- Carcinogenesis spired clinical protocols like the human breast cancer chemoprevention trial using the retinoid fenretinide (3). It has recently been shown that the retinoid LGD 1096 suppresses estrogen receptor- (ER) negative tumor development in virus Erb-b2 transgenic mice (4).

Retinoids bind to nuclear receptors, of 
which there are two classes, RARs and RXRs, with three subtypes $(\alpha, \beta, \gamma)$ in each class. RARs form heterodimers with RXRs, which control gene transcription, binding to specific DNA regions known as retinoid responsive elements (RAREs and RXREs) or interfere with the function of the AP-1 transcriptional factor, which binds to other DNA sites (5). RAR $B$ expression tends to be very low or absent in breast cancer cells when compared to senescing cells (6). ER-positive breast cancer cell lines express higher levels of RAR $\alpha$, compared to ER-negative lines (7).

The exact molecular mechanisms underlying the chemopreventive effects of retinoids are unknown, but probably involve growth regulation and induction of differentiation. These compounds are capable of inhibiting the proliferation of several breast cancer cell lines (8) by inhibiting G1 transition in the cell cycle (9).

An interesting in vitro model of breast cancer progression, in which the action of retinoid can be investigated, is the mouse mammary cell line HC11 (10), and HC11ras, obtained by the stable transfection of a mutated oncogene Ha-ras into HC11 cells (11). $\mathrm{HC} 11$ cells isolated from the normal mammary glands of a midpregnant mouse retain important normal features like the capacity to differentiate and express as a marker the milk protein $B$-casein, after lactogenic hormone induction. HC-11 cells present mutations in both alleles of the p53 tumor suppressor gene (12), which could explain the immortalized phenotype of these cells. HC11 ras cells, in contrast, do not differentiate upon lactogenic hormone exposure and are tumorigenic when injected into immunosuppressed mice (13). A previous study by our group has shown that vitamin D inhibits the proliferation of parental $\mathrm{HC} 11$ cells, but not of Ha-ras-transformed HC11 cells (14).

The objective of the present investigation was to determine the effects of retinoic acid on the growth of the mouse mammary cells $\mathrm{HC} 11$ and $\mathrm{HC} 11$ ras. The expression of the two classes (RARs and RXRs) of retinoic acid receptor mRNAs was measured by Northern blot analysis. Receptor functional integrity was studied by testing whether RAR B mRNA could be induced by retinoic acid, since RAR $\beta$ itself is a retinoid transcriptional target (5). The effects of a 72-h exposure to $50 \mu \mathrm{M} 13$-cis retinoic acid on proliferation of $\mathrm{HC} 11$ and $\mathrm{HC} 11$ ras cells and differentiation of $\mathrm{HC} 11$ cells were investigated by flow cytometric cell cycle analysis and by determination of $ß$-casein mRNA expression, respectively. The possibility that retinoic acid would induce the expression of the vitamin $\mathrm{D}$ receptor (VDR) and synergize with vitamin $\mathrm{D}$, a known inhibitor of $\mathrm{HC} 11$ cell growth, was investigated, since the VDR promoter contains a candidate retinoic acidresponsive element (15).

\section{Material and Methods}

\section{Cell culture}

HC11 cells (donated by Dr. Nancy Hynes, Friedrich Meischer Institute, Basel, Switzerland) were seeded at an initial cell density of $2 \times 10^{4}$ cells $/ \mathrm{cm}^{2}$ and cultured in RPMI 1640 medium supplemented with $10 \%$ fetal calf serum (FCS), $5 \mu \mathrm{g} / \mathrm{ml}$ insulin and $2 \mathrm{mM}$ glutamine. When exposed to $100 \mathrm{nM}$ vitamin D (Biomol Research Laboratories, Inc., Plymouth Meeting, PA, USA), $50 \mu \mathrm{M}$ 13-cis retinoic acid or $10 \mu \mathrm{M}$ 9-cis retinoic acid (Sigma, St. Louis, MO, USA), cells were maintained under the same conditions, except for a 24 -h preculture in $10 \%$ charcoaladsorbed FCS.

\section{Flow cytometric DNA content determination}

Cells were assessed for DNA content using the DNA intercalating agent propidium iodide (16). Analysis was performed with a FACSCalibur flow cytometer (Becton Dickinson, San Jose, CA, USA) and the 
percent of cells in the G0/G1, S and G2/M phases was determined by the ModFit software (Becton Dickinson).

\section{Vitamin D receptor evaluation using a specific monoclonal antibody}

$\mathrm{HC} 11$ cells were grown for $48 \mathrm{~h}$ with or without $10 \mu \mathrm{M}$ 9-cis retinoic acid. The latter was chosen due to its action on both RXRs and RARs, which could possibly imply a greater capacity to trans-activate the target VDR (5). VDR expression was evaluated in indirect immunofluorescence assays using a specific murine monoclobal antibody. Cells were fixed in $70 \%$ cold ethanol and maintained at $-20^{\circ} \mathrm{C}$ for at least $12 \mathrm{~h}$, washed twice in PBS and incubated with $13 \mu \mathrm{g} / \mathrm{ml}$ anti-VDR (VD2F12) (17) for $60 \mathrm{~min}$. Positivity for the marker was identified by enumerating the fraction of cells located above the channel where $1 \%$ positivity was obtained for the background stain. Fluorescence intensity, which reflects the number of antigen molecules/cell, was evaluated on the basis of the mean fluorescence channel.

\section{RNA isolation and Northern blot assays}

Total RNA from $\mathrm{HC} 11$ cells was isolated using the TRIZOL reagent (Gibco-BRL, Rockville, MD, USA). Twenty-microgram samples were electrophoresed on $1 \%$ agarose-3\% formaldehyde gels and the RNA was transferred to Hybond $\mathrm{N}$ nylon filters (Amersham Pharmacia Biotech, Little Chalfont, Buckinghamshire, UK) which were hybridized in 50\% formamide, 5X SSPE, $0.2 \%$ SDS, $5 \%$ dextran sulfate, $5 \mathrm{X}$ Denhardt's solution containing $100 \mu \mathrm{g} / \mathrm{ml}$ salmon sperm DNA, and a $3 \times 10^{6} \mathrm{cpm} / \mathrm{ml}\left[\alpha^{32} \mathrm{P}\right]-\mathrm{dCTP}$ (Amersham) oligo-labeled specific probe using the random primer labeling technique (Klenow fragment of E. coli DNA polymerase; Gibco-BRL, Gaithersburg, MD, USA) for $20 \mathrm{~h}$ at $42^{\circ} \mathrm{C}$. The following fragments were used as probes: a 1.9-kb EcoRI, 1.4-kb SacI/BamHI and $1.5 \mathrm{~kb}$ EcoRI fragments of human RAR $\alpha, \beta$ and $\gamma$, respectively (5), and 4.8-kb EcoRI, 1.7-kb EcoRI/ Pst1, 1.67-kb Asp718/BamHI fragments for RXR $\alpha, \beta$ and $\gamma$, respectively (18), and a 2.1$\mathrm{kb}$ fragment of human VDR cloned at the EcoRI site of pGEM (19). Membranes were washed for $15 \mathrm{~min}$, twice at room tempera-

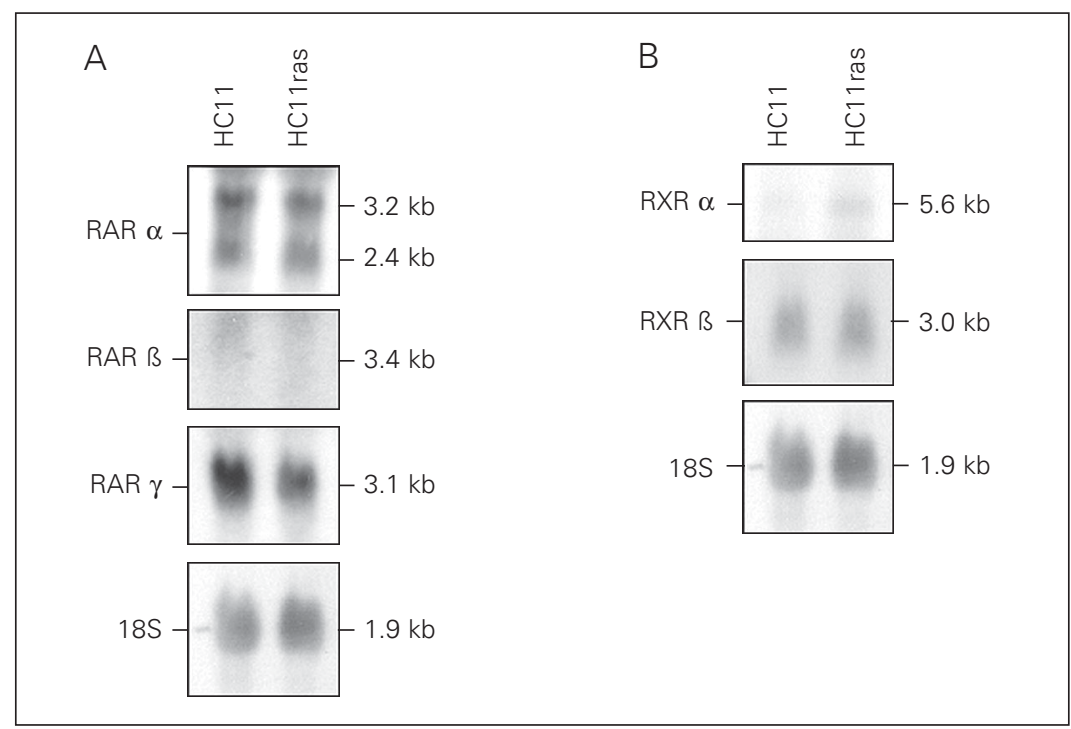

Figure 1. Expression of RAR and RXR in HC11 and HC11 ras cells. Total RNA was subjected to Northern blot analysis and filters were sequentially hybridized with [32P]-labeled probes for RAR $\alpha, \beta$ and $\gamma(\mathrm{A})$ and RXR $\alpha, \beta$ and $\gamma(\mathrm{B})$ and 18S rRNA as a control for RNA loading.

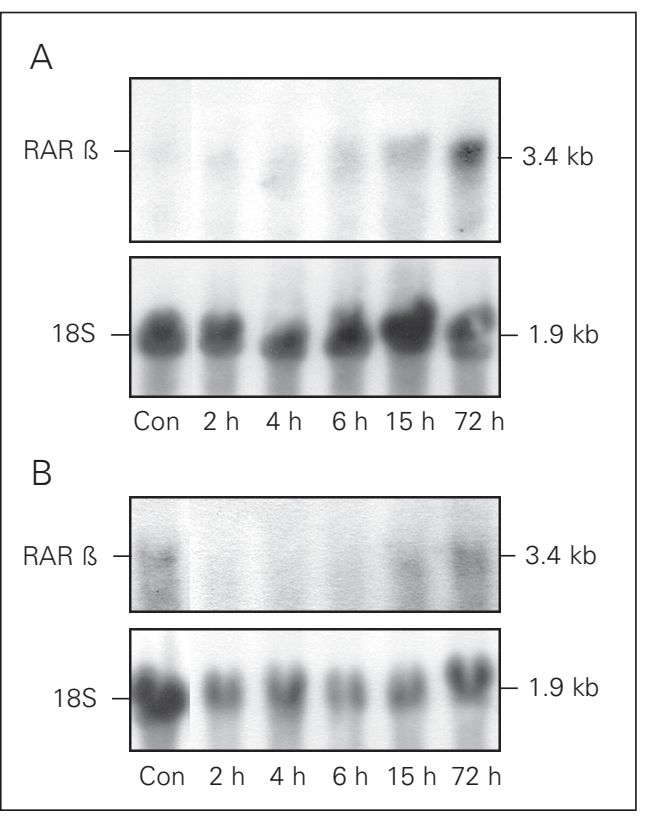

Figure 2. RAR B receptor mRNA expression in retinoic acid-induced $\mathrm{HC} 11$ (A) and HC11ras (B) cells. Cells were exposed or not (Con) to $50 \mu \mathrm{M}$ 13-cis retinoic acid for different times. Total RNA was extracted and subjected to Northern blot analysis and filters were sequentially hybridized with [32P]-labeled probes for RAR $B$ and 18S rRNA as a control for RNA loading. 
Figure 3. Effect of retinoic acid on cell cycle distribution. HC11 (A) and HC11ras (B) cells were grown without (control) or with $50 \mu \mathrm{M}$ 13-cis retinoic acid (RA) for $72 \mathrm{~h}$, harvested, permeabilized and labeled with propidium iodide. DNA content was evaluated by fluorescence intensity, and appears on the $x$-axis as channel numbers. Cell number is depicted on the $y$-axis of the histograms. ture in $2 \mathrm{X}$ SSPE, $0.1 \% \mathrm{SDS}$, once in $1 \mathrm{X}$ SSPE, $0.1 \%$ SDS, once in $0.2 \mathrm{X}$ SSPE, $0.1 \%$ $\mathrm{SDS}$, and finally for $30 \mathrm{~min}$ at $52^{\circ} \mathrm{C}$ in $0.1 \mathrm{X}$ SSPE and $0.1 \%$ SDS. Hybridization with the $18 \mathrm{~S}$ ribosomal RNA probe, a 1.9-kb fragment cloned at the SalI/EcoRI site of plasmid pBR322 (20), was subsequently performed to check for equivalence of RNA loading. Band intensities in autoradiograms were quantified by densitometric scanning (UltroScan XL, Pharmacia LKB Biotechnology, Uppsala, Sweden) and data are reported as the ratio of specific mRNA to $18 \mathrm{~S}$ rRNA. All solutions were prepared as described in Ref. 21.

\section{Differentiation assay}

HC11 cells were induced to differentiate and synthesize the milk protein $\beta$-casein by growing and maintaining the cultures with

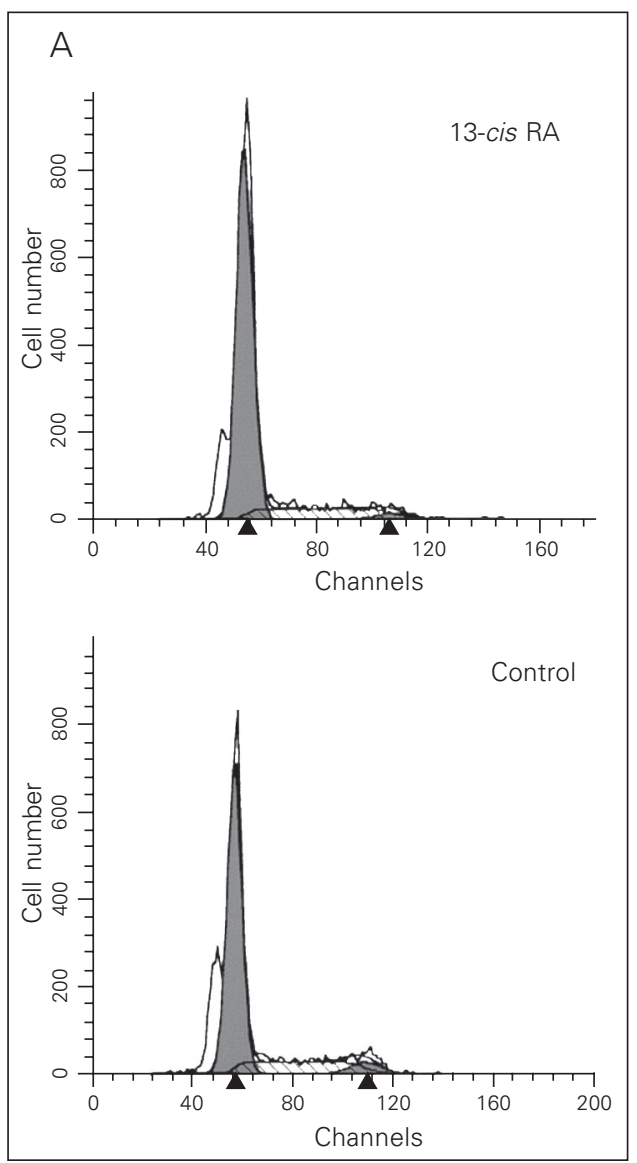

10 ng/ml murine EGF (Sigma). After 3-4 days, EGF was removed and the competent cultures were treated for 3 days with RPMI medium supplemented with $1 \mu \mathrm{M}$ dexamethasone, $5 \mu \mathrm{g} / \mathrm{ml}$ insulin and $5 \mu \mathrm{g} / \mathrm{ml}$ prolactin (DIP).

\section{Results}

\section{Retinoic acid receptor expression}

We started by determining the mRNA of retinoic acid receptors in $\mathrm{HC} 11$ and $\mathrm{HC} 11$ ras cells in order to obtain evidence for a possible responsiveness to retinoids. HC11 cells express approximately two times more mRNA of both RAR $\alpha$ and RAR $\gamma$, when compared to HC11ras cells. RAR B expression, in contrast, was low in both cells (Figure $1 \mathrm{~A})$. RXR $\alpha, \beta$ and $\gamma$ expression was low in both HC11 and HC11ras cells (Figure

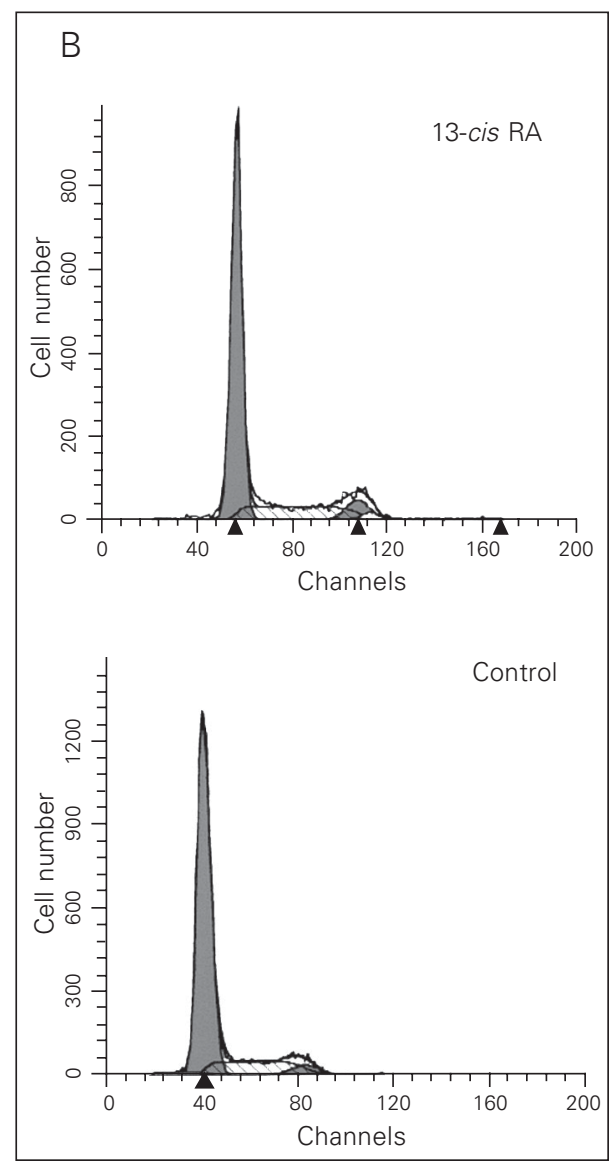


1B). In addition, RAR $\beta$ mRNA was induced after a 72-h treatment with $50 \mu \mathrm{M} 13$-cis retinoic acid, in both $\mathrm{HC} 11$ (Figure 2A) and HC11ras (Figure 2B) cells, by 50- and 2fold, respectively.

\section{S-phase assessment}

We determined the effect of retinoic acid on cell proliferation, on the basis of the cell cycle distribution measured by flow cytometric analysis. Exposure to $50 \mu \mathrm{M} 13$-cis retinoic acid for $72 \mathrm{~h}$ failed to affect the $\mathrm{S}$ phase fraction in both $\mathrm{HC} 11$ and $\mathrm{HC} 11$ ras cells. Representative histograms show an Sphase fraction of 21 and $23 \%$ in control and induced HC11 cells, respectively. Similarly, other representative histograms show an Sphase fraction of 19 and $20 \%$ in control and induced HC11 ras cells, respectively. These results indicate that both $\mathrm{HC} 11$ (Figure 3A) and $\mathrm{HC} 11$ ras (Figure 3B) cells are resistant to the growth-inhibiting effects of high levels of 13-cis retinoic acid.

\section{Differentiation assessment}

Expression of the milk protein $B$-casein mRNA was used as a marker of the differentiation of $\mathrm{HC} 11$ cells. Exposure to $50 \mu \mathrm{M} 13-$ cis retinoic acid for $72 \mathrm{~h}$ failed to induce Bcasein mRNA expression (Figure 4), indicating that retinoic acid had no effect on cell differentiation, in contrast to cells differentiated by exposure to DIP.

\section{Investigation of the combined effect of retinoic acid and vitamin $D$}

Retinoic acid receptors may be functional in these cells, since there was an induction, albeit late (72 h) of de RAR $\beta$ mRNA after treatment with 13-cis retinoic acid. Thus, we wondered whether there could be a sensitization to the growth-inhibiting effect of vitamin D on $\mathrm{HC} 11$ cells by a possible induction of the VDR after exposure to retinoic acid.

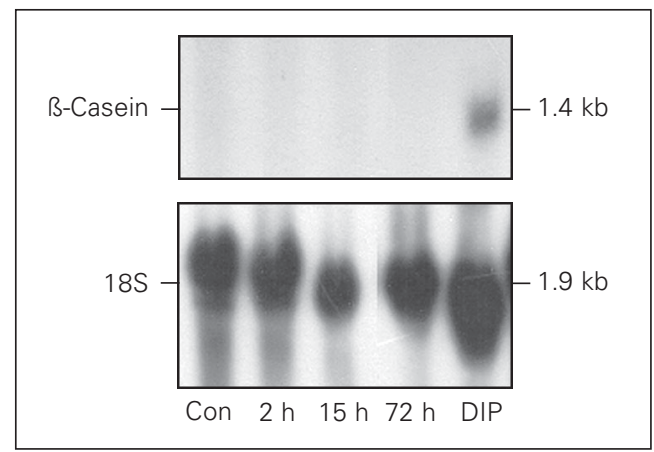

Therefore, we studied the expression of VDR protein by monoclonal antibodies and flow cytometric analysis. There was no increase in the expression level of the VDR protein after a 48-h induction with $10 \mu \mathrm{M}$ 9-cis retinoic acid. VDR expression was detected in more than $80 \%$ of both control and retinoic acid-induced cells (Figure 5). Accordingly, retinoic acid failed to potentiate the antiproliferative effect of vitamin D. The Sphase fraction was 12.2 and $10.0 \%$ after a 72-h induction with $100 \mathrm{nM}$ vitamin $\mathrm{D}$ alone or $100 \mathrm{nM}$ vitamin D plus $50 \mu \mathrm{M}$ 13-cis retinoic acid, respectively (Figure 6).

\section{Discussion}

The expression of retinoic acid receptor mRNAs was initially determined in parental and ras-transformed $\mathrm{HC} 11$ cells. We found that $\mathrm{HC} 11$ cells expressed higher mRNA levels of both RAR $\alpha$ and RAR $\gamma$ as compared to HC11ras cells. In contrast, RAR $\beta$, as well as RXR $\alpha, \beta$ and $\gamma$ expression, was low in both HC11 and HC11 ras cells. RAR $\beta$ expression was shown to be very low in the breast cancer cell lines MCF-7, T-47D, MDAMB-361 and BT-474, as determined at the mRNA level, in contrast to RAR $\alpha$ and RAR $\gamma$ expression, which was variable $(6,7)$. In breast cancer samples, RAR $B$ expression, as determined by in situ hybridization, was lower compared to normal adjacent tissue, in contrast to RAR $\alpha$, RAR $\gamma$ and RXR $\alpha$ which were expressed equally by tumor and normal tissues $(22,23)$. Our results showing a low
Figure 4. B-Casein mRNA expression in $\mathrm{HC} 11$ cells induced with $50 \mu \mathrm{M}$ 13-cis retinoic acid for different times and exposed to $1 \mu \mathrm{M}$ dexamethasone, $5 \mu \mathrm{g} /$ $\mathrm{ml}$ insulin and $5 \mu \mathrm{g} / \mathrm{ml}$ prolactin (DIP). The control (Con) was HC11 cells which were not induced. Total RNA was subjected to Northern blot analysis and filters were sequentially hybridized with [ $\left.{ }^{32} \mathrm{P}\right]$-labeled probes for ß-casein and 18S rRNA as a control for RNA loading. Only DIP treatment induced ß-casein expression, in contrast to retinoic acid, which failed to differentiate the cells. 
Figure 5. Effect of retinoic acid on vitamin D receptor (VDR) protein expression in $\mathrm{HC} 11$ cells. VDR content was evaluated with a monoclonal antibody by flow cytometry analysis. In the histograms, the cell number is shown on the $y$-axis and the fluorescence channel number on the $x$ axis. The open area represents the nonspecific staining and the filled area represents cells specifically labeled with anti-VDR antibody. HC11 cells were grown for $48 \mathrm{~h}$ without (control) or with $10 \mu \mathrm{M}$ 9-cis retinoic acid (RA).
Figure 6. Effect of retinoic acid plus vitamin $D$ on the cell cycle distribution. Cells were exposed to $100 \mathrm{nM}$ vitamin $\mathrm{D}$ alone or $100 \mathrm{nM}$ vitamin D plus $50 \mu \mathrm{M}$ 13-cis retinoic acid (RA) for $72 \mathrm{~h}$, harvested, permeabilized and labeled with propidium iodide. DNA content was evaluated by fluorescence intensity, and appears on the $x$-axis as channel numbers. Cell number is indicated on the $y$-axis of the histograms. Two assays were performed with similar results.
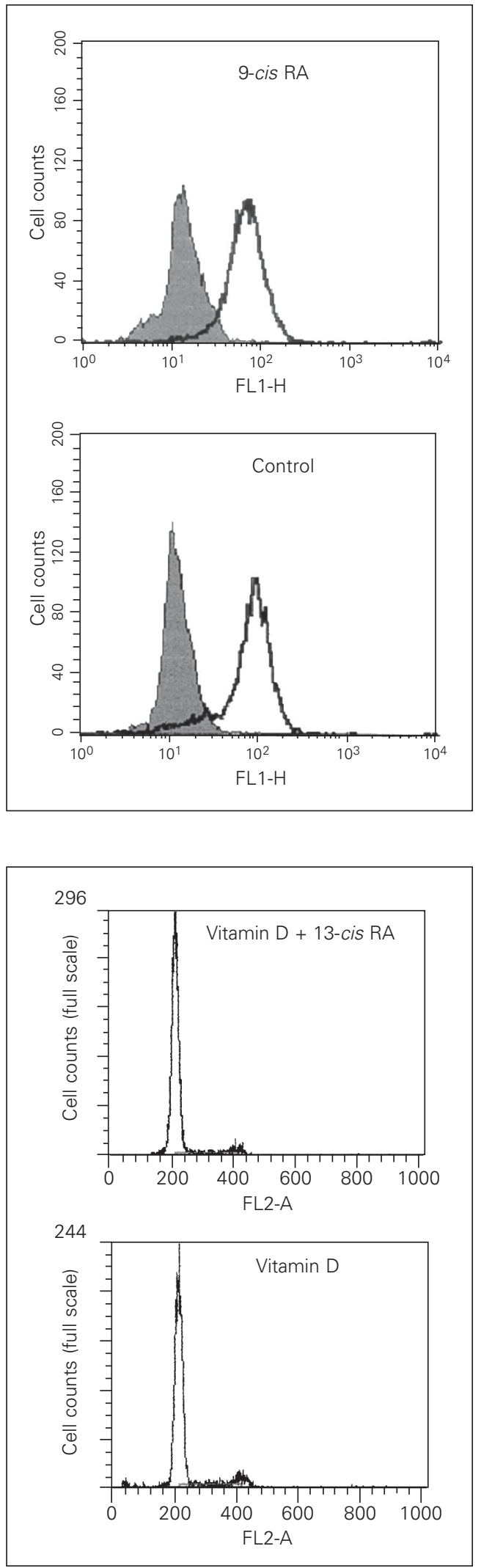

RAR B expression in parental HC11 cells, which present several normal features, contrast with those of another study in which RAR $\beta$ was highly expressed in benign breast lesions (24). We would suggest that the concomitant loss of p53 and RAR $\beta$ might be a marker of progression in the process of carcinogenesis. The RAR $B$ induction seen in $\mathrm{HC} 11$ and HC11ras cells after retinoic acid exposure suggests the presence of functional retinoic receptors, since one of the transcriptional targets of RAR $\beta$ is the RAR $\beta$ gene itself (5). The modest level of induction (2 times) observed in HC11ras cells compared to that seen in $\mathrm{HC} 11$ cells (50 times) could be due to the lower basal expression of RAR $\alpha$ and RAR $\gamma$ of HC11ras cells. Although capable of expressing apparently functional retinoid receptors, both $\mathrm{HC} 11$ cells and HC11ras cells were resistant to the antiproliferative effects of retinoic acid. A possible explanation for these observations is the low RAR \& basal expression, since this specific receptor could be critical to mediate the growth-inhibiting effects, as previously suggested (6). There are, however, conflicting reports concerning the relative importance of these receptors, showing the critical role played either by RAR $\alpha(25,26)$ or by RAR $\gamma$ (27) as mediators of the biological effects of retinoic acid. Another factor possibly associated with resistance to the antiproliferative effect of retinoic acid is the lack of expression of ER, both in $\mathrm{HC} 11$ and HC11ras cells. The ER-negative breast mammary cell line MDA-MB-231, which is retinoic acid resistant, becomes sensitive when stably transfected with ER, although the underlying molecular mechanism remains to be elucidated (28).

We also investigated the effect of retinoid acid on HC11 cell differentiation using B-casein milk protein mRNA expression as a marker. Our results showed no induction of $ß$-casein upon long term exposure to retinoic acid. Our findings are in contrast to another study, in which retinoids were found to be 
capable of inducing differentiation in the breast cancer cell line SKBR3 by regulation of the cadherin adhesion molecule expression and function (29). We cannot rule out the possibility of partial differentiation since ß-casein is a marker of milk production and thus indicates a final stage of differentiation of $\mathrm{HC} 11$ cells.

Our own data (14) had shown that vitamin D inhibits the proliferation of $\mathrm{HC} 11$ but not of HC11ras cells. Since vitamin D induces hypercalcemia, it would be of potential clinical interest to use this compound at lower doses. Thus, we determined whether the addition of retinoic acid to vitamin D could have a synergistic effect on HC11 cells. The S-phase inhibition was similar in both the combination and vitamin D only treatment. These findings are in contrast to those of others, in which this combination was found to be synergistic in MCF-7 and T-47D mammary cells $(30,31)$. The cooperative effects of vitamin $\mathrm{D}$ and retinoic acid could be explained by the formation of VDR/ RXR heterodimers and by the enhancement of the trans-activating capacity (32). Another possible mechanism of synergy could be the induction of VDR by retinoic acid (15). The lack of synergy, alternatively, could be explained by the competition of RAR and
VDR for the partner RXR (33). Thus, there could be either synergy or antagonism with the combination of retinoic acid and vitamin $\mathrm{D}$ depending on the cellular context.

We conclude that the RAR expression profile could be related to the transformed state in HC11 ras cells. A key unknown component in the retinoic pathway may be altered in both parental and ras-transformed HC11 cells. A possible candidate could be the recently identified retinoid target transcriptional factor SOX9, which seems to mediate growth inhibition in breast cancer cell lines (34). The resistance to retinoic acid described here merits further investigation.

\section{Acknowledgments}

We are grateful to Dr. Nancy Hynes (Friedrich Meischer Institute, Basel, Switzerland) for the generous donation of the HC11 and HC11ras cells, to Dr. N. Arnheim (Department of Biochemistry, State University of New York), to Dr. Pierre Chambom (Institut de Chimie Biologique, Faculté de Medecine, Strasbourg, France), and to Dr. Ronald M. Evans (Howard Hughes Medical Institute, San Diego, CA, USA) who kindly donated probes for 18S rRNA, RAR $(\alpha, \beta, \gamma)$ and $\operatorname{RXR}(\alpha, \beta, \gamma)$, respectively.

\section{References}

1. Moon RC, Mehta RG \& Destriac CJ (1992). Retinoids as chemopreventive agents for breast cancer. Cancer Detection and Prevention, 16: 73-79

2. Gandilhon P, Melancon R, Djiane J \& Kelly PA (1982). Comparison of ovariectomy and retinyl acetate on the growth of established 7,12dimethylbenz(a)anthracene-induced mammary tumors in the rat. Journal of the National Cancer Institute, 69: 447-451.

3. Costa A, Formelli F, Chiesa F, Decensi A, De Palo G \& Veronesi U (1994). Prospects of chemoprevention of human cancers with the synthetic retinoid fenretinide. Cancer Research, 54: 2032s-2037s.

4. Wu K, Zhang $Y, X u X C$ et al. (2002). The retinoid $X$ receptor-selective retinoid, LGD1069, prevents the development of estrogen receptornegative mammary tumors in transgenic mice. Cancer Research, 62: 6376-6380.

5. Chambon P (1996). A decade of molecular biology of retinoic acid receptors. FASEB Journal, 10: 940-954.

6. Swisshelm K, Ryan K, Lee X, Tsou HC, Peacocke M \& Sager R
(1994). Down-regulation of retinoic acid receptor beta in mammary carcinoma cell lines and its up-regulation in senescing normal mammary epithelial cells. Cell Growth and Differentiation, 5: 133-141.

7. Roman SD, Clarke CL, Hall RE, Alexander IE \& Sutherland RL (1992). Expression and regulation of retinoic acid receptors in human breast cancer cells. Cancer Research, 52: 2236-2242.

8. Sheikh MS, Shao ZM, Li XS, Dawson M, Jetten AM, Wu S, Conley BA, Garcia M, Rochefort H \& Fontana JA (1994). Retinoid-resistant estrogen receptor-negative human breast carcinoma cells transfected with retinoic acid receptor-alpha acquire sensitivity to growth inhibition by retinoids. Journal of Biological Chemistry, 269: 2144021447.

9. Marth C, Bock G \& Daxenbichler G (1985). Effect of 4-hydroxyphenylretinamide and retinoic acid on proliferation and cell cycle of cultured human breast cancer cells. Journal of the National Cancer Institute, 75: 871-875.

10. Danielson KG, Oborn CJ, Durban EM, Butel JS \& Medina D (1984). 
Epithelial mouse mammary cell line exhibiting normal morphogenesis in vivo and functional differentiation in vitro. Proceedings of the National Academy of Sciences, USA, 81: 3756-3760.

11. Happ B, Hynes NE \& Groner B (1993). Ha-ras and v-raf oncogenes, but not int-2 and c-myc, interfere with the lactogenic hormone dependent activation of the mammary gland specific transcription factor. Cell Growth and Differentiation, 4: 9-15.

12. Merlo GR, Venesio T, Taverna D, Marte BM, Callahan R \& Hynes NE (1994). Growth suppression of normal mammary epithelial cells by wild-type p53. Oncogene, 9: 443-453.

13. Hynes NE, Taverna D, Harwerth IM, Ciardiello F, Salomon DS, Yamamoto T \& Groner B (1990). Epidermal growth factor receptor, but not c-erbB-2, activation prevents lactogenic hormone induction of the beta-casein gene in mouse mammary epithelial cells. Molecular and Cellular Biology, 10: 4027-4034.

14. Escaleira MT \& Brentani MM (1999). Vitamin D3 receptor (VDR) expression in HC-11 mammary cells: regulation by growth-modulatory agents, differentiation, and Ha-ras transformation. Breast Cancer Research and Treatment, 54: 123-133.

15. Miyamoto $K$, Kesterson RA, Yamamoto $H$, Taketani $Y$, Nishiwaki $E$, Tatsumi S, Inoue Y, Morita K, Takeda E \& Pike JW (1997). Structural organization of the human vitamin $D$ receptor chromosomal gene and its promoter. Molecular Endocrinology, 11: 1165-1179.

16. Vindelov LL \& Christensen IJ (1990). A review of techniques and results obtained in one laboratory by an integrated system of methods designed for routine clinical flow cytometric DNA analysis. Cytometry, 11: 753-770.

17. Dame MC, Pierce EA, Prahl JM, Hayes CE \& DeLuca HF (1986). Monoclonal antibodies to the porcine intestinal receptor for 1,25 dihydroxyvitamin $D_{3}$ : interaction with distinct receptor domains. Biochemistry, 25: 4523-4534.

18. Mangelsdorf DJ, Borgmeyer U, Heyman RA, Zhou JY, Ong ES, Oro $A E$, Kakizuka A \& Evans RM (1992). Characterization of three RXR genes that mediate the action of 9-cis retinoic acid. Genes and Development, 6: 329-344.

19. Faraco JH, Morrison NA, Baker A, Shine J \& Frossard PM (1989). Apal dimorphism at the human vitamin $D$ receptor gene locus. Nucleic Acids Research, 17: 2150.

20. Arnheim N (1979). Characterization of mouse ribosomal gene fragments purified by molecular cloning. Gene, 7: 83-96.

21. Maniatis T, Fritsch EF \& Sambrook J (1989). Molecular Cloning: A Laboratory Manual. 2nd edn. Cold Spring Harbor Laboratory, New York.

22. Xu XC, Clifford JL, Hong WK \& Lotan R (1994). Detection of nuclear retinoic acid receptor mRNA in histological tissue sections using nonradioactive in situ hybridization histochemistry. Diagnostic Molecular Pathology, 3: 122-131.

23. Widschwendter M, Berger J, Daxenbichler G, Muller-Holzner E, Widschwendter A, Mayr A, Marth C \& Zeimet AG (1997). Loss of retinoic acid receptor beta expression in breast cancer and morphologically normal adjacent tissue but not in the normal breast tissue distant from the cancer. Cancer Research, 57: 4158-4161.

24. Pasquali D, Bellastella A, Valente A, Botti G, Capasso I, del Vecchio S, Salvatore M, Colantuoni V \& Sinisi AA (1997). Retinoic acid receptors alpha, beta and gamma, and cellular retinol binding protein-I expression in breast fibrocystic disease and cancer. European Journal of Endocrinology, 137: 410-414.

25. Fitzgerald $P$, Teng $M$, Chandraratna RA, Heyman RA \& Allegretto EA (1997). Retinoic acid receptor alpha expression correlates with retinoid-induced growth inhibition of human breast cancer cells regardless of estrogen receptor status. Cancer Research, 57: 2642-2650.

26. Farias EF, Arapshian A, Bleiweiss IJ, Waxman S, Zelent A \& Mira-YLopez R (2002). Retinoic acid receptor alpha2 is a growth suppressor epigenetically silenced in MCF-7 human breast cancer cells. Cell Growth and Differentiation, 13: 335-341.

27. Widschwendter M, Daxenbichler G, Culig Z, Michel S, Zeimet AG, Mortl MG, Widschwendter A \& Marth C (1997). Activity of retinoic acid receptor-gamma selectively binding retinoids alone and in combination with interferon-gamma in breast cancer cell lines. International Journal of Cancer, 71: 497-504.

28. Rosenauer A, Nervi C, Davison K, Lamph WW, Mader S \& Miller Jr WH (1998). Estrogen receptor expression activates the transcriptional and growth-inhibitory response to retinoids without enhanced retinoic acid receptor alpha expression. Cancer Research, 58: 51105116.

29. Shah S, Pishvaian MJ, Easwaran V, Brown PH \& Byers SW (2002). The role of cadherin, beta-catenin, and AP-1 in retinoid-regulated carcinoma cell differentiation and proliferation. Journal of Biological Chemistry, 277: 25313-25322.

30. Saunders DE, Christensen C, Williams JR, Wappler NL, Lawrence WD, Malone JM, Malviya VK \& Deppe G (1995). Inhibition of breast and ovarian carcinoma cell growth by 1,25-dihydroxyvitamin D3 combined with retinoic acid or dexamethasone. Anti-cancer Drugs, 6: $562-569$.

31. Koga M \& Sutherland RL (1991). Retinoic acid acts synergistically with 1,25-dihydroxyvitamin D3 or antioestrogen to inhibit T-47D human breast cancer cell proliferation. Journal of Steroid Biochemistry and Molecular Biology, 39: 455-460.

32. Kliewer SA, Umesono K, Mangelsdorf DJ \& Evans RM (1992). Retinoid $X$ receptor interacts with nuclear receptors in retinoic acid, thyroid hormone and vitamin D3 signalling. Nature, 355: 446-449.

33. Evans TR \& Kaye SB (1999). Retinoids: present role and future potential. British Journal of Cancer, 80: 1-8.

34. Afonja O, Raaka BM, Huang A, Das S, Zhao X, Helmer E, Juste D \& Samuels HH (2002). RAR agonists stimulate SOX9 gene expression in breast cancer cell lines: evidence for a role in retinoid-mediated growth inhibition. Oncogene, 21: 7850-7860. 